\title{
The Historical City between Past and Future. Is the Center Becoming Peripheral?
}

\author{
Antonluca Di Paola1, a \\ ${ }^{1}$ Via Maffei 14, 50133 Florence, Italy \\ aluca.dipaola@gmail.com
}

\begin{abstract}
Keywords: Historical City, Strategies of Rehabilitation, Sustainable Enhancement, New Functions
\end{abstract} and Roles.

\begin{abstract}
The passage from the concept of "historical center" to that of "historical city" involves an expansion of the concept of "historicity" that means a different way to look at the contemporary city. The "historicity" is, in fact, a value attributed to portions of territory, to building/monuments of a time of the past, also recent, that are considered such for rarity, memorializing faculty, beauty. Consequently the first problem is the recognition of the "historical city", which involves individualization and interpretation of the existing values with the purpose to give new functions and roles to those parts of city. This acknowledgement implies a new urban project, new tools of intervention and new planning procedures, according to the demands expressed by the urban communities of the Mediterranean Basin, in Italy and particularly in Libya.
\end{abstract}

\section{Introduction}

In the cities of the Mediterranean coexist in the same degree opportunities and contradictions. Around the urban epicenter, where is often present a notable cultural historical patrimony, in the last decades has been developed a wide area of expansion of settlements, characterized by high building densities, the irrational use of the territory and, especially in the south regions of Italy and the Mediterranean, an increasing of the abusiveness, that resulted in entire districts deprived of services and habitability. Traffic and congested mobility, atmospheric and acoustic pollution, hydrogeological and natural risks, social uneasiness, are among the main problems in a lot of European and Mediterranean cities [1].

The quality of the urban development, as structured in the last decades, requires the enforcement of integrated strategies for the sustainable development of the urban contexts. A strategy already adopted by the European Community that, through various resolutions related to the Thematic Strategies on the Urban environment [COM 2004/60], introduce a broad spectrum of measures with the common objective of dealing with the connected urban and settlement problems.

The dispersion of residential commercial and productive settlements, often localized on vast areas, the needs placed by mobility and allocation of goods and the problems related to the maintenance of natural resources, impose a more effective connection between urban planning and government of the territory. In the broad visual of the integrated urban and social politics, the urban planning represents one of the tools to achieve the objectives of social equity [2].

In prospect of sustainable development, the interconnection between urban and environmental planning is structured with the adoption of policies acquired through "participation". The integration with the general needs of the present sets the conditions for the renewal of the intervention on the territory. In this context, the principle of sustainability and its practical realization allow to overcome the dichotomy between preservation and transformation. A challenge that now more than ever focuses on the specificities of the Mediterranean, which is aimed to establish a model of sustainable development in harmony with the culture, the environmental and materials conditions of the south regions of Europe. 
With the affirmation of new needs and ideas, urban planning and architecture in the Mediterranean basin show the need to play an essential role: to make the city of tomorrow the reflection of an ancient art of living the city and the territory in a sustainable way [3].

In this perspective, the design choices will arise mainly from the enhancement of the social, cultural and environmental factors and from the development of the different alternative scenarios, based on the principles of public benefit. Some basics principles, useful for the design of sustainable cities in the Mediterranean basin, can be summarized as follows: the sustainable city is one that maintains its density (through the reduction of land consumption), urban forms (as an expression of the cultural needs of inhabitants), which protects the green and the access to nature and which promotes a wise use of local materials, in partnership with the innovative technologies.

The "Athens Paper", revisited by many in an ecological key, can be assumed as the founding document of green construction and eco-urbanism of the south. It identifies operational principles still up-to-date for house-building and a sustainable architecture assuming the knowledge of the territory (social, architectural and historical) as the cornerstone of the entire process; the planning choices, according to the Paper, result from the elaboration of alternative scenarios, based on criteria of public utility, cost reduction and of re-evaluation of the social, cultural and environmental factors, with the purpose to develop a global urban project, managed in an integrated and developmental way [4].

The postulates of the Athens Paper regarding the materials are clear and they point straight toward green construction: the cultural and natural patrimony of the urban space must be identified, protected and enhanced. The city must be planned to reduce the traffic, promoting the "soft" movements and the public transportation, preserving the natural resources, among which water, and supporting the energetic autonomy. The urbanization must be governed, in agreement with the population and all the stakeholders: basically every subject with interest in the urban project. A program that can be summarized in three fundamental concepts: recover, preserve and restore.

\section{The historical city between maintenance and transformation}

From these general ideas descend many new Italian urban planning ways and means of intervention, which can be summed up in the following actions:

The city doesn't become larger, it transforms; the first step is underlining the necessity to contain the building expansion in favour of the requalification of pre-existing areas and a better preservation of the residential and environmental quality, through the realization of increasing quota of social residential housing. The action is set to oppose the processes of urban dispersion and the prediction of expansion; to encourage a lower territorial impact building philosophy, and the preservation of the agricultural marginal areas.

The city transforms and renews itself, mainly through interventions of requalification and repurposing of the historical city, considered in its complexity and historical stratification, and through functional districts, set in the peripheral areas. The intervention in the functional district will be based on criteria of elevated architectural and environmental quality and it will develop contextually to the expansion of the infrastructures, with the purpose to form a network of relationships among the parts of the city. The historical city will be therefore one of the functional districts of the city that must find the reasons for its survival in relation to other functions and present services: the green areas, the areas designed for sports, the doorways to the city (railway stations, airports, harbours), the public management and commercial centers, the university districts.

The requalification of the city; the third step is the wide urban requalification, actions of diffused maintenance of the public and green spaces, of protection of the buildings of historical interest, of improvement of the energetic accessibility and efficiency. In order to meet this goal many Italian cities, among which Rome, Milan, Reggio Emilia and many others, have adopted a methodology that, overcoming the concept of zoning, identifies homogeneous circles, the "tissues", 
individualized according to a qualitative logic. A classification based on settlement characteristics, typology, function, services and scenarios that allow to direct the intervention toward targeted and differentiated actions.

The city is modernized; the fourth step identifies actions aimed to improve the system of the mobility, both urban and in the outskirts, the reorganization of the productive and commercial areas; oversees the reorganization of the railway transport, the resolution of the knots of ineffectiveness of the urban road network, through traffic plans. The new urbanizations, whether residential, tertiary or commercial, in this new organization of the mobility, must be developed only in correspondence of the infrastructural great knots. Regarding the rearrangement of the productive and commercial areas, the strategies put in place will address the containment of dispersive installations and the expansion, diversification and qualification of the commercial network. The more complex shopping centers will be located in correspondence of the major traffic knots, in order to attract costumers on a provincial or even regional level. For the historical center, the objective is to increase the attraction potential, encouraging commerce and craftsmanship.

The strengthening of the public city; through a facilities Plan, the requalification of the public spaces, plazas, roads, street furniture and through the realization of social housing for the weakest classes.

The territory recognizes and enhances its resources. The sixth strategy is directed to spread territorial quality, both in urban and extra urban circles. The strategy concerns the landscape, the safeguard of the agricultural land, the diffused historical building assets, the expansion of ecological networks and biodiversity. Regarding the landscape and the areas of natural and environmental value, the methodology more used contemplates the identification of macro areas of intervention, divided in systems identifiable for geomorphologic characteristics. For the agricultural territory, the rules of safeguard and the application formalities for urban planning and building are reevaluated in a perspective of differentiation of the interventions in relation to the typologies of goods, of settlement containment and of protection of landscape and territory [5].

\section{Is the historical center the new periphery?}

The historical city, inside this territorial organization, must redefine its role, to offer some suitable services, as a place of residence, of cultural offer, as a privileged place for education: from the classical school system, to the wide range of educational activities, intended for the different demands based on age, purposes or culture. Also beauty plays its role, as already underlined by Camillo Sitte and Luwis Mumford in the first decades of the XX centuries.

In the historical city two societies live side by side: a "legitimate", permanent one, located in the historical center and in the residential areas, and an "illegitimate" one, which consist of migrant, clandestine, permanent workers, and students. Among the two societies there is a deep incomprehension and an attitude of refusal. Therefore, the center, as the outskirts, brings about factors of urban blight [6].

Among the various sectors, commerce shows the deepest changes: more and more stores are managed by migrants from south east Asia. Over the years the historical center has become a melting pot of different cultures: of immigrants, commuters and "off-site" visitors. All these categories display a great heterogeneity of ethical and religious values and of behavioural models. If before the identity of a place was draw from history, politics or the job structure, now trading defines the spaces of the city. Although trading is natural to the historical centers, through the network of shops, suks, and markets, today, especially in the metropolitan areas, it holds a greater power to permeate the urban structure [8].

The historical center now appears as a portion of the city for some aspects progressively emptied of part of its functions, for others inaccessible to part of the population and contextually refused as place of residence, assigned in the end to a role of space destined to leisure by public policies in 
support of tourist activities. The historical city now appears as the center of activities distant among themselves and apparently incompatible, for geographical origin, for culture and for reference with the fast rhythm of the modern daily life [9].

Will the historical city find a metropolitan and territorial dimension to ensure its survival? The strength of its image is strong enough to hope in its survival even under the assaults of the current globalized market, where the real estate investments are driven by groups and specialized companies, that find in the demolition of part of the city more or less degraded, new market opportunities. Many theorize a new application of the "building thinning", introduced by Gustavo Giovannoni in the years ' 30 of the XX century, that today assumes as character of urban regeneration [10].

Projects nevertheless carry little planning innovation and they are often reduced to projects of skyscrapers, structures that are markers of the financial power that has built them.

The greatest novelties are not therefore to be seen in the grandiosity of the interventions, as much as in the practice, already diffused in a lot of Italian cities, and in the ever advancing research of reading, safeguarding and planning the historical, consolidated and suburban city, in the punctual research of safeguard of the environmental values, structural to the territory: a practice perhaps not immediately visible, but that will allow the survival of the historical city and that immense settlement structure that characterizes the Italian and Mediterranean territory: one "city of cities."

\section{Reference}

[1] F. Ascher: Los nuevas principios del urbanismo, Madrid, Alianza Ensayo (2004)

[2] M. Auge': Rovine e macerie, Torino, Bollati Boringhieri (2004)

[3] B. Bonfantini: Progetto urbanistico e città esistente, Milano, Clup (2002)

[4] A. Di Paola: La carta di Atene dalla ville radieuse alla città sostenibile, in Fallanca C.(by), Spazio e Società, edizioni Centro Stampa Ateneo, Reggio Calabria (2010)

[5] C. Brandi: Il nuovo sul vecchio, La fiera letteraria (settembre 1964), ora in M. Cordaro (a cura di): Restauro. Teoria e pratica, Roma (1994)

[6] M. Galligari Galli: Il centro è periferia, in F. Evangelisti, P. Orlandi, M. Piccinini (a cura): La città storica contemporanea, Bologna, Editai (2008)

[7] P. Donadieu: Una nuova proposta di paesaggio, Roma, Donzelli, (2006)

[8] C. Martinotti: Metropoli. La nuova morfologia sociale della città, Bologna, Il Mulino, (1993)

[9] P.O. Rossi: L'indagine sulla città contemporanea come contributo alla carta per la qualità, del nuovo piano regolatore di Roma, in: F. Evangelisti, P. Orlandi, M. Piccinini (a cura)...op. cit..

[10] G. Giovannoni: Vecchie città ed edilzia, nuova 1931, ristampa F.Ventura (by), edizioni Città degli studi,Torino (1995) 